\title{
Ethmoid Sinus Squamous Cell Carcinoma
}

National Cancer Institute

\section{Source}

National Cancer Institute. Ethmoid Sinus Squamous Cell Carcinoma. NCI Thesaurus.

Code C6065.

A squamous cell carcinoma that arises from the mucosal epithelial surface of the ethmoid sinus. Patients may present with nasal fullness, obstruction, and/or epistaxis. 